Authors' Contribution: A Study Design

B Data Collection

C Statistical Analysis

D Data Interpretation

E Manuscript Preparation

F Literature Search

G Funds Collection

\section{The role of myofascial massage in spinal pains in professionally active women}

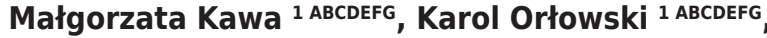 \\ Małgorzata Kowza-Dzwonkowska 2 ABDEFG
}

${ }^{1}$ Department of Physiotherapy, Faculty of Rehabilitation and Kinesiology, Gdansk
University of Physical Education and Sport in Gdansk, Poland

2 Department of Health Promotion, Faculty of Tourism and Recreation, Gdansk University of Physical Education and Sport in Gdansk, Poland

\title{
abstract
}

Background Pain ailments of the spine are one of the most common diseases of the system of bones and joints. $75 \%$ to $85 \%$ of the world's population suffer or will suffer from it, and lumbar pain is the most common cause of disability of persons over 45 years of age. They are usually the beginning of a chronic, often progressing ailments often leading to disability, incapacity to work and restrictions in daily life. Myofascial massage helps reduce pain sen sations. Is a specific method of gradual stretching soft tissues and making muscle fibres more elastic. It reduces increased muscle tone, muscle insertions and tendons.

Material/Methods The study involved 30 women with a mean age of 52.7 years. The study relied on performing 10 myofascial massages of the spine within 2 weeks.

Results The statistical analysis of the Wilcoxon's signed-ranked test showed statistically significant results for tested variables of the Laitinen scale (the intensity of pain before and after the treatment at $p=0.00$, the incidence of pain before and after the treatment at $p=0.00$, the use of analgesics before and after the treatment at $p=0.00$, limitation of physical activity before and after the treatment at $p=0.00$ ).

Conclusions The applied therapy involving a series of myofascial massages supporting the structures of the motor segment, improving the elasticity of the massaged tissues and normalising the muscle tone resulted in reducing pain ailments in the lumbo-sacral section of the spine. Improvement in the patients' well-being and increased desire for physical activity took place.

Key words pain, lumbar spine, myofascial massage, deep tissue massage, women

\section{article details}

Article statistics

Full-text PDF:

Copyright

Indexation:

Funding:

Conflict of interest: Corresponding author:

Open Access License:
Word count: 2,370; Tables: 2; Figures: 1; References: 30

Received: September 2015; Accepted: November 2015; Published: December 2015

http://www.balticsportscience.com

(c) Gdansk University of Physical Education and Sport, Poland

AGRO, Celdes, CNKI Scholar (China National Knowledge Infrastructure), CNPIEC, De Gruyter - IBR (International Bibliography of Reviews of Scholarly Literature in the Humanities and Social Sciences), De Gruyter - IBZ (International Bibliography of Periodical Literature in the Humanities and Social Sciences), DOAJ, EBSCO - Centra \& Eastern European Academic Source, EBSCO - SPORTDiscus, EBSCO Discovery Service, Google Scholar, Index Copernicus, J-Gate, Naviga (Softweco, Primo Central (ExLibris), ProQuest - Family Health, ProQuest - Health \& Medical Complete, ProQuest - Illustrata: Health Sciences, ProQuest - Nursing \& Allied Health Source, Summon (Serials Solutions/ProQuest, TDOne (TDNet), Ulrich's Periodicals Directory/ulrichsweb, WorldCat (OCLC)

This research received no specific grant from any funding agency in the public, commercial, or not-for-profit sectors.

Authors have declared that no competing interest exists.

Mgr Małgorzata Kowza-Dzwonkowska; Pracownia SPA \& Wellness, Akademia Wychowania Fizycznego i Sportu im. J. Śniadeckiego w Gdańsku, ul. K. Górskiego 1, 80336 Gdańsk; phone no.: +48 58554 74 74; e-mail: mkd@awf.gda.pl

This is an open access article distributed under the terms of the Creative Commons Attribution-Non-commercial 4.0 International (http://creativecommons.org/licenses/by-nc/4.0/), which permits use, distribution, and reproduction in any medium, provided the original work is properly cited, the use is non-commercial and is otherwise in compliance with the license. 


\section{INTRODUCTION}

Pain in the lower section of the spine has been the main concern of public health in developed countries for many years. All over the world 75\% to $85 \%$ of the population suffer or will suffer from it, and lumbar pain is the most common cause of impairment among persons over 45 years of age [1, 2]. Pain syndromes of the spine are counted among civilisation diseases [3]. Epidemiological data clearly indicate that pain syndromes and other disorders related to the spine now constitute one of the fundamental medical as well as socio-economic problems $[4,5]$.

In the pathogenesis of spinal pains, an important role is played by changes in the intervertebral disc as well as intervertebral joints and ligaments of the spine. Regardless of the starting point of pain ailments, pathological changes involve the motor segment of the spine. With increasing pathology, disorders can affect various structures within the motor segment, as well as adjacent and distant organs. This is associated with the common segmental origin of these structures in the ontogenetic development. There are many causes of pain ailments in the lower section of the spine. These include inborn defects of movement organs, a low level of physical fitness, and the nature, extent, frequency, and duration of adverse mechanical factors affecting the spine. Incorrect and unergonomic exploitation of the spine lies at the root of most of the causes of aches and pains. Mastering the correct motor patterns of the spine is a relatively easy task. Appropriate and healthy lifestyle aims to prevent the incidence of disease [6, 7].

Pains in the lumbar spine now represent an interdisciplinary problem. Proper treatment of patients with pain syndromes of the lower section of the spine is a multi-specialist treatment. Among others, it includes physiotherapy, pharmacotherapy, and educating the patient and his/her family. The main objective in the treatment of pain disorders of the spine is to enable the patient to return to the desired level of motor activity and prevent their recurrence [8].

An important role in pain syndromes of the spine is played by the fascial and ligament system. Fascia is the connective tissue that surrounds and joins organs and muscles. Attention to its specific role was drawn in 1993 [8]. Fascia creates a network of thin connective tissue membranes intersecting at different levels of the body. They surround muscles or muscle groups, generating septa between them, and therefore they influence the shape of muscles and their movability relative to each other. Functions of fasciae include several ranges of activity. Fascia, as a wrapping for all body structures, connecting and separating them, is a mechanical protection of organs, and thanks to the presence of contractile cells and receptors in the fascia, it has a stabilising function. Fascia creates and marks paths and channels for veins, arteries and nerves. Fascia also plays an important role in all metabolic processes, as it participates in the formation of internal organs $[9,10]$.

Massage is frequently applied in the therapy of spinal ailments. Massage accelerates regeneration of tissues, and it alleviates the pain sensation [11, 12]. It improves the functioning of people with chronic pain of the lower section of the spine $[13,14]$. There are many varieties of massage. In the treatment of pain disorders, myofascial massage, also called deep tissue massage is used increasingly more often. The benefits of applying deep tissue massage 
include improving the flow of lymph, improving blood circulation, eliminating adhesions, improving ranges of motion, reducing muscle tension, stretching muscles and fasciae, supporting a trigger point therapy, improving muscle function, and regaining muscle balance [15]. Functional disorders of the spine, aches and pains of muscles and myofascial structures surrounding it as well as prophylaxis are all indication for its use. This treatment can also be used in states of exhaustion, in recovery and as revitalising massage.

Myofascial massage is a treatment aimed at relaxing tensions in muscles and fasciae based on massage techniques adapted from various concepts of fascial massage. It is a form of massage that relaxes tissues, improves their movability and releases tension in an efficient and ergonomic way. The treatment begins with a functional assessment of the patient and an assessment of his/ her myofascial system. An initial application of relaxing harmonic techniques, according to E. Ledermann, is a preparation for the massage. The procedure is performed with a use of typical fascial techniques in conjunction with techniques developed by S. Lief and B. Chaitow in the method of neuromuscular therapy on the abdominal side of the patient. At the end of the massage of the back fascial mobilization is performed by affecting a deeper layer of the fascia. Techniques in myofascial massage are very effective if the "soft, deep, slow" principle is applied in the masseur's work $[16,17,18]$. The basic rule in performing myofascial massage is cooperation between the patient and the therapist. Gradual stretching of soft tissues is applied in the massage according to guidelines based on a reaction of the patient's tissues [16]. Myofascial massage affects the connective tissue, streamlining the flow of blood and lymph. It boosts metabolism, lowers muscular tension, and reduces pain ailments of the spine [19].

In pain ailments of the spine, an important role is played by fascia of the erector spinae, which along with the gluteus maximus muscle and the iliotibial tract constitutes a whole. When performing myofascial massage, a massage of buttocks should be an integral part of a massage of the back [9, 10]. Equally important is the thoracolumbar fascia, which is one of the most complex fasciae of the body. According to Langevin et al., it can cause pain in the lower spine [20].

The thoracolumbar fascia is a key structure in transferring tensions between muscles of the back, the abdomen and the sciatic-tibial muscle. It should be considered in the evaluation of disorders occurring in the muscle groups in the back, abdomen, and the limbs. There are numerous causes of disorders in the myofascial system. Schuenke's et al. research confirms that the thoracolumbar fascia surrounding the spinal muscles is simultaneously connected to the muscles forming the abdominal wall [21]. The same research indicates that the thoracolumbar fascia, partly built of fibres of paraspinal muscles fasciae and partly of fibres of muscle aponeurosis, creates a compact unity with muscles the lower part of the trunk. Currently various techniques are used in order to normalize fascial tension, and myofascial massage is an increasingly used method of relieving pain in lower back [22].

The aim of the study was to assess the effectiveness of myofascial massage in reducing pain, limiting the use of analgesics and increasing physical activity in professionally active women with chronic pain in the lower section of the spine. 


\section{MATERIAL AND METHODS}

A diagnostic survey method was selected for the research, and the techniques included a questionnaire survey - a modified questionnaire of Laitinen's pain indicators and a patient's card. In the applied research technique, attention was paid to the accurate and truthful filling in questionnaires. The intensity of pain of the lower section of the spine, the incidence of pain, the frequency of painkiller use and limitations in physical activity were evaluated. The surveys were conducted twice - before and after the therapy. Myofascial massage included work in order to relax and stretch muscles which limit the ability of the spine to move in the full range of motion. The therapy was conducted on the spine in a position that stretched stiff muscles to allow a greater range of motion in the limited direction [23].

The results were subjected to statistical analysis using Statistica 7.1 software (StatSoft, Poland).

\section{SUBJECTS' CHARACTERISTICS}

The study comprised 30 professionally active women with chronic pain in the lumbosacral section of the spine. The subjects' mean age was 52.7 years, and the mean weight was $66.1 \mathrm{~kg}$. Each subject was given a series of ten myofascial massages over two weeks.

\section{RESULTS}

A statistically significant reduction in the average values (point) of the intensity of pain on the Laitinen scale was found in the conducted study. To verify the significance of differences between the results before and after applying a series of myofascial massages, Wilcoxon test was used.

Table 1. The level of significance of the conducted study

\begin{tabular}{ll}
\hline Wilcoxon test of the sequence of pairs & Level of significance \\
\hline Pain intensity before and after therapy & 0.000004 \\
\hline Pain incidence before and after therapy & 0.000004 \\
\hline Use of analgesics before and after therapy & 0.00004 \\
\hline Limitation in physical activity before and after therapy & 0.000008 \\
\hline$p<0.05$ &
\end{tabular}

As can be seen from the above data, results in the research group are statistically significant in each conducted study. 


\section{Percentage Results on the} Laitinen Scale

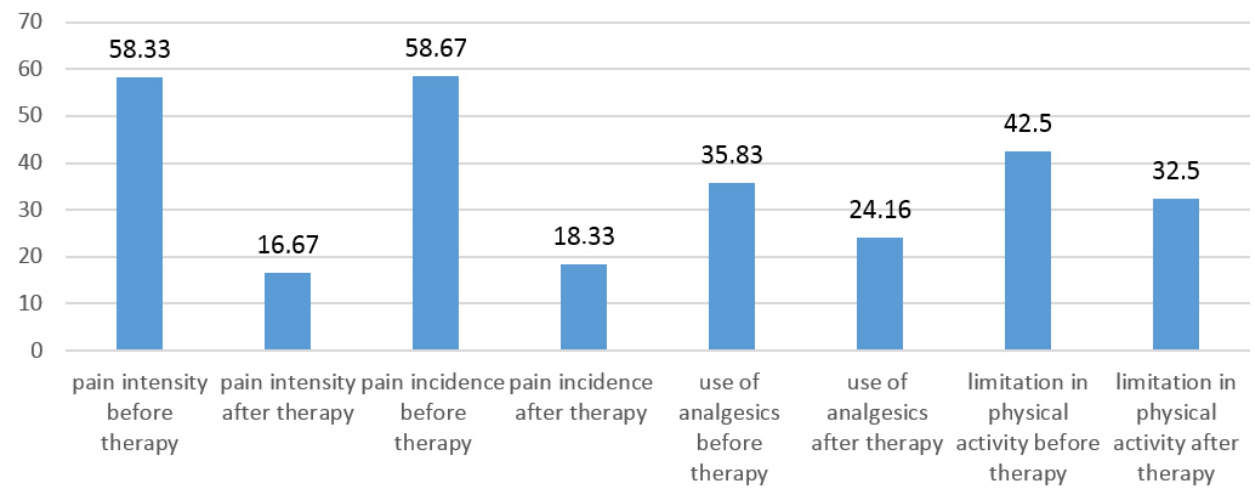

Fig. 1. An assessment of the effectiveness of myofascial massage in the treatment of pain in the lower section of the spine

In the studied group, the level of pain intensity before a series of 10 myofascial massages was $58.33 \%$. After the treatment pain intensity dropped to the level of $16.67 \%$ indicating a statistically significant difference. The decrease in pain intensity after the application of deep tissue massage in the treatment of the lower back pain disorders proved to be an effective treatment for the subjects.

The presented data show a statistical significance in the study of the incidence of pain. Pain incidence decreased from $58.33 \%$ to $18.33 \%$, which significantly improved the subjects' functioning in daily life.

It appears from the percentage distribution of the use of painkillers that before applying the treatment it amounted to $35.83 \%$. The decrease after treatment was $24.16 \%$, which constitutes a statistically significant difference.

Limitation of physical activity among the studied group before the treatment amounted to $42.50 \%$. After 10 myofascial massages there was a statistically significant decline in physical activity restrictions, which amounted to $32.5 \%$.

The level of correlations between of pain intensity, incidence of pain, use of painkillers, limitation in physical activity and the subjects' age, body weight and occupation was also examined.

Table 2. Correlation between age, body weight, and performed profession and the selected pain indicators among the subjects

\begin{tabular}{llcc}
\hline Correlation & Age & Profession & Body weight \\
\hline Pain intensity after therapy & -0.034195 & 0.092407 & -0.025682 \\
\hline Pain incidence after therapy & 0.103865 & -0.248947 & -0.052643 \\
\hline Use of analgesics after therapy & 0.182314 & -0.031529 & -0.041941 \\
\hline Limitation in physical activity after therapy & 0.077824 & -0.024875 & 0.023931 \\
\hline
\end{tabular}

Correlations are significant with $\mathrm{p}<0.05, \mathrm{~N}=30$ 
On the basis of the study results, a low level of correlation between the subjects' age, weight and performed profession and the selected pain indicators was found.

\section{DISCUSSION}

Myofascial massage can be an effective complement to the comprehensive treatment of pain disorders in the lower section of the spine. Medical literature describes various causes of pain disorders of the spine. However, there are few studies concerning the effectiveness of massage in the treatment of pain problems of the lower section of the spine. This is due to the difficulty in obtaining an objective assessment the massage effectiveness.

The aim of the study was to assess the effectiveness of myofascial massage and its influence on pain intensity, pain incidence, and use of analgesics and limitation of physical activity. A significant reduction in the intensity of pain and an analgesic effect of myofascial massage was found in pain ailments of the lower spine among the tested persons.

Kassolik et al. proved in their research that massage therapy decreases pain in the cervical spine and improves patients' mental status [24]. Witoś et al. also showed that hot stone massage influences a reduction in pain [25]. Reduced intensity of pain in the lumbar section was shown in their study of Ćwirlej et al. [26]. Increasing the range of motion of the spine and alleviating pain ailments of the spine are the primary objectives of therapeutic massage [26, 24].

Chochowska's et al. research shows that classical massage combined with a vibrating massage of trigger points relieves symptoms of pain disorders of the spine and leads to improved mood in the elderly [27]. Massage has a positive impact on the improvement in mobility and the reduction of pain problems related to the spine [28].

After 20 weeks of myofascial therapy, an experimental group showed a reduction in pain $(20.6 \pm 6.3, \mathrm{p}<0.032)$, an improvement in physical fitness $(56.10 \pm 17.3 ; \mathrm{p}<0.029)$ and a reduction in clinical symptoms $(5.08 \pm 1.03$, $\mathrm{p}<0.039$ ). Six months after the intervention, the experimental group had a significantly lower mean number of painful points [29].

Richardson et al., focusing their research on ailments of the lower spine, identified two ways of improving muscle mechanics and their stability. The first is reducing the forces exerted on the spine when performing a movement. The second is improving the functioning of the deep muscles system. The use of these theories in practice does not always bring the expected results. However, on the basis of his clinical experience, Chaitow confirms that at the beginning of the therapy one should focus on the shortened muscles, then on the weakened ones [30]. Stretching the shortened muscles leads to automatic restoration of the tonus of hypotonic antagonistic muscles as a result of elimination of braking off on the part of hypertonic muscles.

Aches and pains of the lower section of the spine are so severe that in consequence they may lead to disability and difficulty in performing everyday activities. The biggest problem for the studied women was high intensity of 
pain and a high degree of its incidence. After an application of 10 mobilising myofascial massages, the pain began to decrease, and its incidence was at a much lower level. Similar results were obtained in studies by Kassolik et al. [24], Witoś et al. [25] and Chochowska et al. [27].

\section{CONCLUSIONS}

Myofascial massage contributed to a reduction in pain ailments of the lower spine among the surveyed women. The subjects showed a reduction in the frequency of pain and the use of analgesics as well as an increase in physical activity.

In the literature of the subject there are few publications confirming the effectiveness of deep tissue massage in the treatment of pain disorders of the lower section of the spine, its impact on improving the functioning and an increased desire for physical activities. Due to a limited number of scientific research in this area, exploration of knowledge in terms of the effectiveness of myofascial massage should be continued.

\section{REFERENCES}

[1] Brox JI, Storheim K, Grotle M, Tveito TH, Indahl A, Eriksen HR. Evidence-informed management of chronic low back pain with back schools, brief education, and fear-avoidance training. Spine J. 2008;8(1):28-39.

[2] Jacob T, Zeev A. Are localized low back pain and generalized back pain similar entities? Results of a longitudinal community based study. Disabil Rehabil. 2006;28(6):369-377.

[3] Fritz S. Masaż leczniczy: bóle dolnego odcinka kręgosłupa i miednicy [Therapeutic massage: pain in the lower spine and the pelvis]. 1st ed. Wrocław: Elsevier Urban \& Partner; 2009. Polish.

[4] Dega W, Marciniak W, Szulc A. Ortopedia i rehabilitacja [Orthopedics and rehabilitation]. Warszawa: Wyd. Lekarskie PZWL; 2003. Polish.

[5] Osborn M, Smith JA. The personal experience of chronic benign lower back pain: An interpretative phenomenological analysis. Br J Pain. 2015;9(1):65-83.

[6] Stodolny J. Choroba przeciążeniowa kregosłupa: epidemia naszych czasów [The overload disease of the spine: epidemic of our time]. Kielce: Wydaw. ZL Natura; 2000. Polish.

[7] Kuligowski T, Pioro A, Czerwinski B. State of knowledge about low back pain associated with overload. Med Biol Sci. 2015;28(4):37-42.

[8] Yahia LH, Pigeon P, DesRosiers EA. Viscoelastic properties of the human lumbodorsal fascia. J Biomed Eng. 1993;15(5):425-429.

[9] Ciechomski J. Manipulacje powieziowe - nowy koncept w terapii manualnej [Fascial manipulation a new concept in manual therapy]. Prakt Fizjoterapia Rehabil. 2014;47:6-15. Polish.

[10] Drobner Z. Głeboki masaż mobilizująco-powięziowy kregosłupa [Deep mobilizing myofascial massage of the spine]. Częstochowa: Studio Astropsychologii; 2011. Polish.

[11] Kaye AD, Kaye AJ, Swinford J, et al. The Effect of Deep-Tissue Massage Therapy on Blood Pressure and Heart Rate. J Altern Complement Med. 2008 Mar;14(2):125-128.

[12] Furlan AD, Giraldo M, Baskwill A, Irvin E, Imamura M. Massage for low-back pain. Cochrane Database Syst Rev. 2015 Sep 1;9:CD001929.

[13] Cherkin DC, Sherman KJ, Kahn J, et al. A comparison of the effects of 2 types of massage and usual care on chronic low back pain: a randomized, controlled trial. Ann Intern Med. 2011;155(1):1-9.

[14] Furlan AD, Brosseau L, Imamura M, Irvin E. Massage for low-back pain: a systematic review within the framework of the Cochrane Collaboration Back Review Group. Spine. 2002;27(17):1896-1910.

[15] Wytrążek M, Chochowska M, Marcinkowski JT. Masaż tkanek głebokich - konieczne podejście terapeutyczne wobec narastającej epidemii chorób narządu ruchu [Deep tissue massage - necessary therapeutic approach to the growing epidemic of musculoskeletal diseases]. 2013;94 (3):428-434. Polish.

[16] Manheim C. Rozluźnianie mięśniowo-powięziowe [Myofascial relaxation]. Poznań: Wyd. WSEiT; 2011. Polish.

[17] Ratajska M, Chochowska M. Rozluźnianie mięśniowo-powięziowe wg Carole Manheim - jako innowacyjne uzupełnienie fizjoterapii w pierwszym okresie po rewaskularyzacji tętnic wieńcowych [Myofascial relaxation by Carole Manheim as an innovative complement to physiotherapy in the first period after coronary revascularization]. Hygeia. 2013;48(4):400-407. Polish. 
[18] Kasprzak W, Mankowska A. Fizykoterapia, medycyna uzdrowiskowa i SPA [Physiotherapy, Medical health resort and Spa]. Wydawnictwo Lekarskie PZWL; 2008. Polish.

[19] Zborowski A. Masaż klasyczny [Classical massage]. Firma Wydawniczo-Handlowa AZ; 2006. Polish.

[20] Langevin HM, Fox JR, Koptiuch C, et al. Reduced thoracolumbar fascia shear strain in human chronic low back pain. BMC Musculoskelet Disord. 2011;12:203.

[21] Schuenke MD, Vleeming A, Van Hoof T, Willard FH. A description of the lumbar interfascial triangle and its relation with the lateral raphe: anatomical constituents of load transfer through the lateral margin of the thoracolumbar fascia. J Anat. 2012;221(6):568-576.

[22] Willard FH, Vleeming A, Schuenke MD, Danneels L, Schleip R. The thoracolumbar fascia: anatomy, function and clinical considerations. J Anat. 2012;221(6):507-536.

[23] Riggs A. Deep Tissue Massage: A visual guide to techniques. North Atlantic Books; 2007.

[24] Kassolik K, Andrzejewski W, Kaczmarski T, Trzęsicka E. Masaż leczniczy w zmianach zwyrodnieniowych szyjnego odcinka kręgosłupa [Therapeutic massage in degenerative changes of the cervical spine]. Fizjoterapia Kwart. 2005;13(4):53. Polish.

[25] Witoś M, Podbielska H, Demczuk-Włodarczyk E. Termowizyjna ocena zmian temperatury w okolicy grzbietowej pod wpływem masażu relaksacyjnego gorącymi kamieniami [Thermal imaging assessment of changes in temperature in the dorsal under the influence of a relaxing massage with hot stones]. Acta Bio-Opt Inform Medica Inż Biomed. 2009;15(3):239-243. Polish.

[26] Ćwirlej A, Ćwirlej A, Maciejczak A. Efekty masażu leczniczego w terapii bólów kręgosłupa [The effects of therapeutic massage in the therapy of back pain]. Przegląd Med Uniw Rzesz. 2007;3:253257. Polish

[27] Chochowska M, Marcinkowski JT, Rąglewska P, Babiak J. Masaż klasyczny i masaż wibracyjny punktów spustowych bólu w leczeniu zespołu bólowego kręgosłupa z towarzyszącym mu obniżeniem nastroju - u osób starszych [Classical massage and vibration massage of trigger points of pain in the treatment of the spinal pain syndrome with the associated depressed mood in elderly people]. Probl Hig Epidemiol. 2011;92(3):428-435. Polish.

[28] Szubzda M, Kaźmierczak U, Hagner W, Dzierżanowski M. Wpływ masażu leczniczego na poprawę ruchomości i zmniejszenie dolegliwości bólowych kręgosłupa [The effect of therapeutic massage on improvement in mobility and reducing back pain]. Fizjoterapia Pol. 2007;7(2):165-170. Polish.

[29] Castro-Sánchez AM, Matarán-Peñarrocha GA, Arroyo-Morales M, Saavedra-Hernández M, Fernández-Sola C, Moreno-Lorenzo C. Effects of myofascial release techniques on pain, physical function, and postural stability in patients with fibromyalgia: a randomized controlled trial. Clin Rehabil. 2011;25(9):800-813.

[30] Chaitow L. Techniki energii mięśniowej [Techniques of muscular energy]. Elsevier Urban \& Partner; 2011. Polish. 